\author{
Renata Rettinger, Piotr Staszak \\ Uniwersytet Pedagogiczny \\ im. Komisji Edukacji Narodowej w Krakowie
}

\title{
Europejskie połączenia lotnicze głównych regionów turystycznych Azji Południowo-Wschodniej
}

\section{Znaczenie dostępności komunikacyjnej (w szczególności lotniczej) w rozwoju ruchu turystycznego Azji Południowo-Wschodniej}

Transport ma podstawowe znaczenie w zaspokajaniu potrzeb związanych z uprawianiem turystyki. Umożliwia turyście zarówno dotarcie do miejsca docelowego podróży, jak i poruszanie się w obrębie odwiedzanego regionu (miejscowości). Obok funkcji komunikacyjnej transport w turystyce zapewnia także realizację funkcji rekreacyjno-rozrywkowej. Niektóre ze środków transportu są wykorzystywane bowiem przez turystów właśnie z tego powodu, a odbywana nimi podróż stanowi atrakcję turystyczną samą w sobie, np. rejs statkiem wycieczkowym czy przejażdżka kolejką widokową.

W historii turystyki dostrzega się wyraźną zależność pomiędzy postępem $\mathrm{w}$ dziedzinie transportu a stanem rozwoju turystyki. Pojawienie się nowych rozwiązań technologicznych $\mathrm{w}$ transporcie, zwiększających jego zdolności przewozowe (w aspekcie ilościowym i przestrzennym) oraz podnoszących komfort podróży, w stosunkowo krótkim czasie doprowadziło do intensyfikacji wyjazdów w celach turystycznych. W XIX w. impulsem do rozwoju turystyki stał się transport kolejowy, natomiast w XX w. - transport samochodowy oraz lotniczy. Współcześnie istniejące środki transportu umożliwiają dotarcie do wszystkich zakątków Ziemi, a jedynymi ograniczeniami związanymi z ich wykorzystywaniem w obsłudze turystów są stan rozwoju infrastruktury transportowej oraz koszt ich użytkowania (Pawlusiński 2007). W dalszym ciagu pewnymi barierami dla rozwoju turystyki jest sytuacja polityczna oraz poziom bezpieczeństwa. W przypadku podróży międzykontynentalnych najważniejsze znaczenie ma transport lotniczy ze względu na nieporównywalnie krótszy czas podróży, niemożliwy do osiagnięcia przez inne środki transportu. Ograniczona ilość czasu na podróże biznesowe oraz te o charakterze turystycznym determinuje rozwój tego właśnie środka transportu.

Według Milewskiego (2008) bardzo ważnym czynnikiem rozwoju ruchu turystycznego w obecnych czasach stał się rozwój i zastosowanie do masowych przewozów pasażerskich transportu lotniczego. Rozpoczęta po drugiej wojnie światowej nowa epoka komunikacji lotniczej osiągnęła w latach 60. XX w. punkt kulminacyjny, gdy wprowadzono do eksploatacji silniki odrzutowe. Transport lotniczy umożliwił wówczas zwiększenie dystansu podróżowania i skrócenie czasu podróży, przez co stał się podstawowym sposobem komunikacji w dalekich podróżach zagranicznych, w tym międzykontynentalnych. W latach 70. wprowadzono do eksploatacji samoloty szerokokadłubowe, co spowodowało skrócenie czasu załadunku i wyładunku bagażu na lotniskach oraz pozwoliło zabierać na pokład większą liczbę pasażerów. Na przełomie lat 80. i 90. w niektórych samolotach wprowadzono zmiany w konstrukcji, które umożliwiły znaczne zmniejszenie zużycia paliwa, to zaś wpłynęło na obniżenie kosztów przewozu pasażerów i ładunku. Wszystkie te osiągnięcia techniczne sprawiły, że przeloty 
samolotami stały się dużo tańsze niż ćwierć wieku temu. W efekcie - dzięki rozwojowi lotnictwa cywilnego turyści w krótkim czasie docierają do miejsc oddalonych od siebie o tysiące kilometrów, niemal niedostępnych dla innych środków transportu. Można stwierdzić, że turystyka międzykontynentalna rozwija się obecnie głównie dzięki transportowi lotniczemu - jego udział w przewozach pasażerskich rośnie wraz z odległością podróży. Na liniach krótszych rola ta również jest znaczna, zwłaszcza w przypadku przelotu nad zatokami, cieśninami, między wyspami, nad pustyniami i terenami bagiennymi lub górzystymi.

Od wielu lat przemysł lotniczy ma duże znaczenie w rozwoju gospodarki krajów regionu Azji Południowo-Wschodniej, chociaż na przestrzeni lat zmienił się jego zasadniczy cel. Po II wojnie światowej linie lotnicze odgrywały ważną rolę w integracji narodów, zwłaszcza w przypadku wyspiarskich, rozproszonych krajów, takich jak Indonezja, Filipiny czy Malezja. Kiedy gospodarka zaczęła przyspieszać, położono nacisk na scalanie krajowych ekonomik z międzynarodowymi, odsuwając na drugi plan cele społeczne. Uważa się, że trzy strategiczne sektory gospodarki są ściśle zależne od rozwoju połączeń lotniczych pomiędzy Azją Południowo-Wschodnią a resztą świata: produkcja, usługi biznesowe oraz turystyka. Turystyka jest bardzo blisko powiązana z lotnictwem. Nawet w bardzo dobrze rozwiniętych rynkach usług turystycznych, takich jak na przykład Bangkok, jedno dodatkowe międzynarodowe połączenie lotnicze może mieć dostrzegalny wpływ na wielkość zysków i zatrudnienia w sektorze turystyki oraz dla ekonomii w szerszej perspektywie (Bowen 2000).

Region Azji i Pacyfiku jest najdynamiczniej rozwijającym się rynkiem turystyki przyjazdowej na świecie. W przeciaggu lat 2000-2008 osiagnięto tu wzrost przyjazdów turystów zagranicznych wynoszący 67,2\% (74 mln ludzi). Subregion Azji Południowo-Wschodniej w 2008 r. odwiedziło 70,9\% (czyli 36,1 mln) więcej turystów niż 8 lat wcześniej. Najliczniej odwiedzanym krajem regionu Azji Południowo-Wschodniej jest Malezja, którą odwiedziło w 2008 r. 22,1 mln turystów zagranicznych. W odniesieniu do roku poprzedniego odnotowano wzrost o $1,1 \mathrm{mln}$ osób (5,2\%). Sąsiednia Tajlandia przyjęła 14,6 mln turystów, co przekłada się na wzrost o 100 tys. $(0,6 \%)$. Singapur odnotował w analogicznym okresie $7,8 \mathrm{mln}$ przyjazdów, co daje spadek wynoszący 200 tys. (2,5\%). W przypadku wpływów z turystyki największe dochody w regionie osiaga Tajlandia, a na drugiej pozycji jest Malezja. Prognozuje się, że znaczenie turystyki w omawianym regionie będzie rosło. Udział przyjazdów turystów zagranicznych do regionu Azji Wschodniej i Pacyfiku wzrośnie w 2020 r. do ok. 25\% przy równoczesnym spadku udziału przyjazdów do Europy i Ameryki.

\section{Rozwój infrastruktury portów lotniczych w glównych miastach Azji Południowo-Wschodniej}

Infrastruktura transportu lotniczego wykazuje pewne podobieństwo do innych gałęzi transportu. Składają się na nią elementy liniowe i punktowe - lądowiska oraz porty lotnicze krajowe i międzynarodowe (Rydzkowski, Wojewódzka-Król 2009). Jednym z najważniejszych problemów współczesnego lotnictwa jest nowoczesny potencjał infrastrukturalny portów lotniczych. Wzrastające potrzeby w zakresie obsługi pasażerów i ładunków wymagają ciagłego inwestowania $\mathrm{w}$ modernizację oraz rozbudowę poszczególnych elementów infrastrukturalnego wyposażenia. Południowo-wschodnioazjatyckie porty lotnicze są najlepszym przykładem daleko posuniętych działań inwestycyjnych, zmierzających do przekształcenia wybranych portów lotniczych w nowoczesne huby. Tendencja ta jest powszechna i występuje we wszystkich dużych metropoliach miejskich świata, w tym także Polski (Wójtowicz 2005). 
Tab. 1. Parametry głównych portów lotniczych Azji Południowo-Wschodniej

\begin{tabular}{|l|c|c|c|}
\hline \multicolumn{1}{|c|}{ Porty lotnicze } & $\begin{array}{c}\text { Odległość } \\
\text { od centrum } \\
\text { aglomeracji } \\
\text { (w km) }\end{array}$ & $\begin{array}{c}\text { Powierzchnia } \\
\text { terminali } \\
\text { pasażerskich (w m } \mathbf{~ m}^{\mathbf{2}}\end{array}$ & $\begin{array}{c}\text { Przepustowość } \\
\text { roczna } \\
\text { (w mln pasażerów) }\end{array}$ \\
\hline Bangkok Suvarnabhumi & 30 & 563000 & 45 \\
Kuala Lumpur International & 50 & 479404 & 35 \\
Singapur Changi & 17 & 1045020 & 70 \\
\hline
\end{tabular}

Źródło: opracowanie własne na podstawie stron internetowych portów lotniczych ujętych w tabeli.

Wszystkie omawiane porty lotnicze przechodzą intensywne zmiany infrastrukturalne. Port lotniczy Bangkok Suvarnabhumi (,Złota Ziemia”), zlokalizowany ok. $30 \mathrm{~km}$ na wschód od Bangkoku, został oddany do użytku w 2006 roku, po 4 latach budowy. Prawie cały ruch międzynarodowy został przeniesiony tu z lotniska Don Mueang w Bangkoku w związku z osiągnięciem maksymalnej pojemności portu oraz brakiem możliwości dalszego rozwoju lotniska uważanego za jedno z najbardziej ruchliwych lotnisk w Azji. Suvarnabhumi jest przystosowany obecnie do obsługi $45 \mathrm{mln}$ pasażerów rocznie, samoloty mogą startować i lądować tu symultanicznie, nie kolidując ze sobą. Docelowo po dodaniu dodatkowych pasów startowych i dalszej rozbudowie port lotniczy będzie mógł przyjąć nawet $100 \mathrm{mln}$ podróżnych. Infrastruktura lotniska pozwala na obsługę wszystkich typów pasażerskich statków powietrznych. Swoje bazy mają tu m.in. narodowe linie lotnicze Tajlandii Thai Airways oraz tani przewoźnik Thai Air Asia. Obecnie komunikację publiczną z centrum metropolii zapewniają ekspresowe linie autobusowe, a na ukończeniu jest naziemna linia kolejowa skorelowana z systemem BTS (metro i Sky Train) w Bangkoku. Konstrukcja lotniska (połączenie szkła i metalu w nawiązaniu do tradycyjnej architektury tajskiej) sprawia, iż Suvarnabhumi uważany jest przez wielu doświadczonych podróżników za jeden z najładniejszych i najbardziej eleganckich portów lotniczych świata.

Lotnisko Kuala Lumpur International pretendujące do miana jednego z najważniejszych węzłów komunikacji lotniczej w Azji Południowo-Wschodniej położone jest w miejscowości Sepang, ok. $50 \mathrm{~km}$ na południe od stolicy Malezji. Podobnie jak w przypadku Bangkoku również i tu port lotniczy w obecnej lokalizacji został oddany do użytku stosunkowo niedawno, bo w 1998 r. Oryginalna architektura obiektu nawiązuje do koncepcji „lotnisko w lesie, las wewnątrz lotniska”, w myśl której budynki terminali głównego oraz tzw. satelitarnego otoczone są lub wkomponowane pomiędzy drzewa przeniesione z lasu deszczowego. Pojemność portu wynosi obecnie $35 \mathrm{mln}$ pasażerów, a docelowo, po rozbudowie, wzrośnie do ok. 100 mln. Najdogodniejszym sposobem dotarcia na lotnisko z centrum Kuala Lumpur jest podróż ekspresowym pociagiem, która trwa ok. 30 minut. Dla wygody pasażerów (obecnie tylko czterech linii lotniczych) funkcjonuje usługa określana mianem „lotniska w mieście”, dzięki której podróżni mogą dokonać wstępnej odprawy i nadać swój bagaż rejestrowany na dworcu kolejowym w centrum miasta. Port lotniczy Kuala Lumpur jako pierwszy oddzielił w sposób dość wyraźny ruch tzw. tanich przewoźników od przewoźników tradycyjnych. W tym celu wybudowano osobny terminal obsługujący tylko pasażerów linii niskokosztowych (oferujący dużo niższy standard), który jest obecnie rozbudowywany w związku z osiągnięciem jego maksymalnej pojemności. Omawiany port lotniczy jest główną bazą flagowego przewoźnika Malezji Malaysia Airlines oraz największej taniej linii lotniczej Azji Air Asia. Infrastruktura portu pozwala na przyjęcie wszystkich komercyjnych statków powietrznych, w tym A380 
- największego samolotu pasażerskiego świata. Warto wspomnieć, że port lotniczy Kuala Lumpur został wyróżniony w rankingu Skytrax tytułami prestiżowego, czterogwiazdkowego oraz 7. najlepszego lotniska świata (obok np. Amsterdamu i Zurychu). Skytrax uznał również standard tutejszej obsługi imigracyjnej za najwyższy na świecie.

Port lotniczy Singapur Chiangi zlokalizowany jest we wschodniej części państwa-miasta i jest największym hubem lotniczym w Azji Południowo-Wschodniej, zwłaszcza w odniesieniu do tzw. trasy kangurowej, biegnącej pomiędzy Europą a Australią. Pod koniec lat 70. XX w. w wyniku gwałtownie rosnącego ruchu lotniczego zadecydowano o budowie nowego lotniska, które mogłoby sprostać potrzebom szybko rozwijającej się metropolii. Pierwszy terminal nowego portu lotniczego otworzono w 1981 r. Sukces Singapuru jako węzła komunikacji lotniczej opiera się m.in. na umiejętnym planowaniu rozwoju infrastruktury portu. W momencie, kiedy nowo otwarte lotnisko spełniało w sposób wystarczający potrzeby ruchu pasażerskiego, postanowiono rozpocząć budowę Terminala 2. Gdy w 1990 r. nowy terminal świecił jeszcze pustkami, projektowano już kolejny (który oddano do użytku w 2008 r. z przeznaczeniem dla statków powietrznych sojuszu Star Alliance). Podobnie jak w przypadku Kuala Lumpur, również i tu przewoźnicy z sektora low cost korzystają z osobnego budynku. Singapur Changi jest przystosowany do obsługi $70 \mathrm{mln}$ pasażerów rocznie. Trzon komunikacji publicznej obsługującej połączenia z centrum metropolii stanowi metro, którym podróż trwa ok. 30 minut. W porcie lotniczym ma swoją macierzystą bazę m.in. narodowy przewoźnik Singapuru, Singapore Airlines (pierwszy odbiorca samolotu A380), uznawany za jedną z najlepszych linii lotniczych świata. Singapur Changi zapewnia jeden z najwyższych standardów obsługi podróżnych wśród portów lotniczych świata. Jest on laureatem wielu prestiżowych nagród w branży lotniczej.

\section{Wielkość międzykontynentalnego ruchu pasażerskiego na trasach europejskich}

W miarę zwiększania zasięgu przestrzennego ruchu turystycznego, a także postępu technicznego i technologicznego, Azja Południowo-Wschodnia stała się jedną z ciekawszych destynacji turystów europejskich. Szybkość, jako główny postulat przewozowy, spowodowała, że coraz częściej za cel podróży wybiera się regiony turystyczne znacznie oddalone od miejsca zamieszkania. Przykładem takiego regionu turystycznego są Tajlandia, Malezja i Singapur, których porty lotnicze znajdują się w azjatyckiej czołówce (tab. 2).

Tab. 2. Największe lotniska Azji

\begin{tabular}{|l|c|c|c|}
\hline \multicolumn{1}{|c|}{ Porty lotnicze } & $\begin{array}{c}\text { Liczba obsłużonych } \\
\text { pasażerów } \\
\text { w 2008 r. (w mln) }\end{array}$ & $\begin{array}{c}\text { Zmiana \% } \\
\text { w odniesieniu do } \\
\text { roku poprzedniego }\end{array}$ & Pozycja w świecie \\
\hline Tokio Haneda & 66,7 & $-0,2$ & 4 \\
Pekin & 55,9 & 4,4 & 8 \\
Hong Kong & 47,8 & 1,7 & 12 \\
Bangkok Suvarnabhumi & 38,6 & $-6,3$ & 18 \\
Singapur Changi & 37,6 & 2,7 & 20 \\
Dubai & 37,4 & 9 & 19 \\
\hline
\end{tabular}

Źródło: opracowanie własne na podstawie danych Airports Council International.

Wielkość ruchu pasażerskiego na trasach pomiędzy omawianymi metropoliami a Europa wykazuje pewne zróżnicowanie. Pomiędzy latami 2007 a 2008 w Singapurze ruch ten wzrósł 
o 5,5\%, a w przypadku Bangkoku i Kuala Lumpur spadł - odpowiednio o 2,9\% i aż 10\%. We wszystkich portach poddanych analizie najbardziej obłożonym połączeniem jest trasa do i z Londynu. Z linii Bangkok-Londyn skorzystało w 2008 r. blisko 754 tys. pasażerów, samolotami z Singapuru do Londynu lub odwrotnie przeleciało 414 tys. osób, natomiast lot pomiędzy stolicami Malezji i Wielkiej Brytanii wybrało 400 tys. podróżnych. Wszystkie analizowane lotniska odnotowały spadek liczby podróżnych na tej trasie. W przypadku Bangkoku wynosił on $-5,7 \%$, Singapuru $-0,7 \%$, a Kuala Lumpur $-6,6 \%$.

Tab. 3. Liczba bezpośrednich lotów pomiędzy Bangkokiem, Kuala Lumpur i Singapurem a portami lotniczymi Europy

\begin{tabular}{|c|c|c|c|c|c|c|c|c|c|}
\hline \multirow{4}{*}{$\begin{array}{c}\text { Docelowy } \\
\text { port } \\
\text { lotniczy } \\
\text { w Europie }\end{array}$} & \multicolumn{9}{|c|}{ Początkowy port lotniczy w Azji } \\
\hline & \multicolumn{3}{|c|}{ Kuala Lumpur International } & \multicolumn{3}{|c|}{ Bangkok Suvarnabhumi } & \multicolumn{3}{|c|}{ Singapur Changi } \\
\hline & \multicolumn{2}{|c|}{ liczba lotów } & \multirow{2}{*}{$\begin{array}{c}\text { przybliżony } \\
\text { czas przelotu } \\
\text { Azja-Europa }\end{array}$} & \multicolumn{2}{|c|}{ l. lotów } & \multirow{2}{*}{$\begin{array}{c}\text { przybliżony } \\
\text { czas przelotu } \\
\text { Azja-Europa }\end{array}$} & \multicolumn{2}{|c|}{ l. lotów } & \multirow{2}{*}{$\begin{array}{l}\text { przybliżony } \\
\text { czas przelotu } \\
\text { Azja-Europ? }\end{array}$} \\
\hline & dziennie & tygodniowo & & dz. & tyg. & & dz. & tyg. & \\
\hline Amsterdam & 2 & 14 & 13:05 & & 13 & $12: 00$ & 2 & 14 & $12: 40$ \\
\hline Ateny & & & & & 3 & $11: 10$ & & 2 & $12: 00$ \\
\hline Frankfurt & & 9 & 13:00 & 4 & 28 & $11: 50$ & 3 & 21 & 13:00 \\
\hline Helsinki & & & & & 13 & $10: 50$ & & & \\
\hline Istambuł & & 3 & $11: 30$ & 1 & 7 & $10: 45$ & & 5 & $12: 00$ \\
\hline Kopenhaga & & & & & 13 & $12: 00$ & & 3 & $13: 00$ \\
\hline Londyn & 2 & 14 & $13: 30$ & 5 & 35 & 13:05 & 3 & 21 & 14:00 \\
\hline Manchester & & & & & & & & 3 & 14:05 \\
\hline Mediolan & & & & & 3 & $12: 35$ & 1 & 7 & $13: 15$ \\
\hline Monachium & & & & & 10 & $11: 55$ & & 5 & 13:05 \\
\hline Moskwa & & & & & 4 & $10: 10$ & & 4 & 11:05 \\
\hline Paryż & & 5 & $13: 25$ & 2 & 14 & $12: 40$ & 2 & 14 & $13: 40$ \\
\hline Rzym & & 3 & $12: 45$ & & 3 & $11: 50$ & & 2 & $13: 05$ \\
\hline Sztokholm & & & & 1 & 7 & $11: 20$ & & & \\
\hline Wiedeń & & & & & 10 & $11: 25$ & & & \\
\hline Zurich & & & & 2 & 14 & $12: 30$ & & 12 & $13: 10$ \\
\hline RAZEM & & 48 & & & 177 & & & 113 & \\
\hline
\end{tabular}

Źródło: opracowanie własne na podstawie rozkładów lotów dostępnych na stronach internetowych portów lotniczych ujętych w tabeli, linii lotniczych oraz sojuszu lotniczego Star Alliance (dla sezonu zimowego 2009). 
Turyści korzystający z transportu lotniczego przy wyborze linii lotniczej, a nawet destynacji, zwracają uwagę przede wszystkim na cenę usługi przewozowej. W dalszej kolejności znajdują się: czas podróży, bezpieczeństwo, komfort lotu oraz poziom i zakres świadczonych usług. Europa jako jeden z głównych obszarów generujących światowy ruch turystyczny posiada liczne połączenia lotnicze z ważniejszymi portami lotniczymi Azji (tab. 3). W przypadku lotniczych przewozów turystycznych duże znaczenie ma nie tylko sieć połączeń, ale też ich częstotliwość.

W aktualnie obowiązującym (sezon zimowy 2009) rozkładzie lotów między omawianymi metropoliami a Europą przewoźnicy oferują łącznie ok. 338 lotów (w pewnych okresach liczba ta może ulegać zmianie). Najwięcej połączeń oferuje Bangkok, bo aż 177. Singapur zapewnia 113 lotów do Europy tygodniowo, natomiast Kuala Lumpur jedynie 48. Przybliżony czas lotu (na trasie Azja Pd.-Wsch.-Europa, bo w przeciwną stronę jest on krótszy) wynosi zazwyczaj 12-13 godzin. Najdłuższe z połączeń wykonywane jest pomiędzy Singapurem a Londynem i Manchesterem - czas podróży wynosi ok. 14 godzin. Najbliżej omawianego regionu położona jest Moskwa; przelot z Bangkoku do stolicy Rosji trwa ok. 10 godzin. Możliwości tranzytowe moskiewskich lotnisk nie są jednak w pełni wykorzystywane ze względu na ograniczoną ofertę bezpośrednich dalekodystansowych połączeń. Na tle ogólnoświatowej siatki połączeń międzykontynentalnych z Azją Pd.-Wsch. Europa ma największe znaczenie (ryc. 1).

Ryc. 1. Europejskie połączenia z portem lotniczym w Singapurze

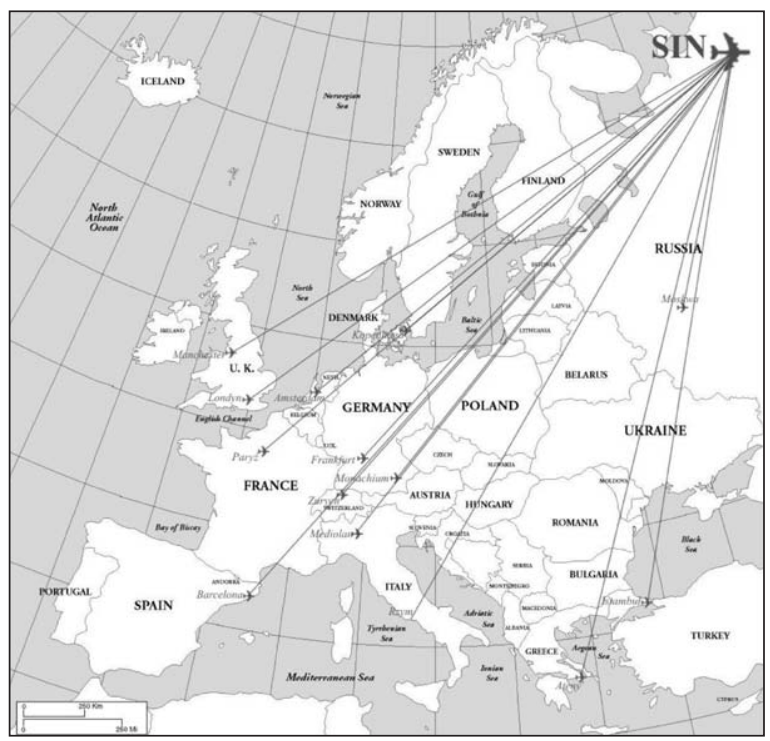

Źródło: opracowanie własne na podstawie www.changiairport.com

Najsłabiej skomunikowanym z azjatyckimi portami lotniczymi regionem świata jest Ameryka Południowa. Jedyne rozkładowe połączenie lotnicze spośród omawianych portów utrzymuje Kuala Lumpur. Z Malaysia Airlines dwa razy w tygodniu polecimy do Buenos Aires. Czas przelotu wynosi ok. 24 h 30 min, a po drodze przewidziane są dwa międzylądowania w RPA: w Johannesburgu i Kapsztadzie. Wszystkie trzy poddane analizie lotniska zapewniają komunikację powietrzną z afrykańskimi miastami położonymi na dwóch skrajnych częściach kontynentu: Johannesburgiem i Kairem. Natomiast jedynie z Bangkoku dotrzemy bezpośrednim 
samolotem do dwóch krajów Afryki Wschodniej: Etiopii (Addis Abbeba) i Kenii (Nairobi). W przypadku Australii wszystkie ważniejsze miasta kontynentu są połączone z omawianymi portami azjatyckimi, w tym także połączeniami typu low cost. Jeśli chodzi o rynek Ameryki Północnej najważniejsze znaczenie ma Singapur, w którego rozkładzie lotów znajduje się aż 9 destynacji północnoamerykańskich. Większość statków powietrznych lecących do USA wykonuje międzylądowanie w jednym z portów Azji Wschodniej (w Hong Kongu: loty do Hartford, San Francisco i Chicago, w Seulu - loty do San Francisco oraz w Tokio: loty do Seattle, Minneapolis, Los Angeles i Denver) lub Europy (w Moskwie: loty do Houston i we Frankfurcie: loty do Nowego Jorku). Ponadto Singapore Airlines proponują dwa bezpośrednie, transpacyficzne połączenia z Los Angeles i Nowym Jorkiem. Trasa Singapur-Nowy Jork jest najdłuższym komercyjnym, bezpośrednim połączeniem pasażerskim na świecie, z czasem przelotu wynoszącym około 18 godzin. Podróż odbywa się wyłącznie w klasie biznes. Żaden $\mathrm{z}$ trzech portów poddanych analizie nie posiada w swojej siatce połączeń destynacji kanadyjskich.

Ryc. 2. Europejskie połączenia lotnicze portu lotniczego w Bangkoku

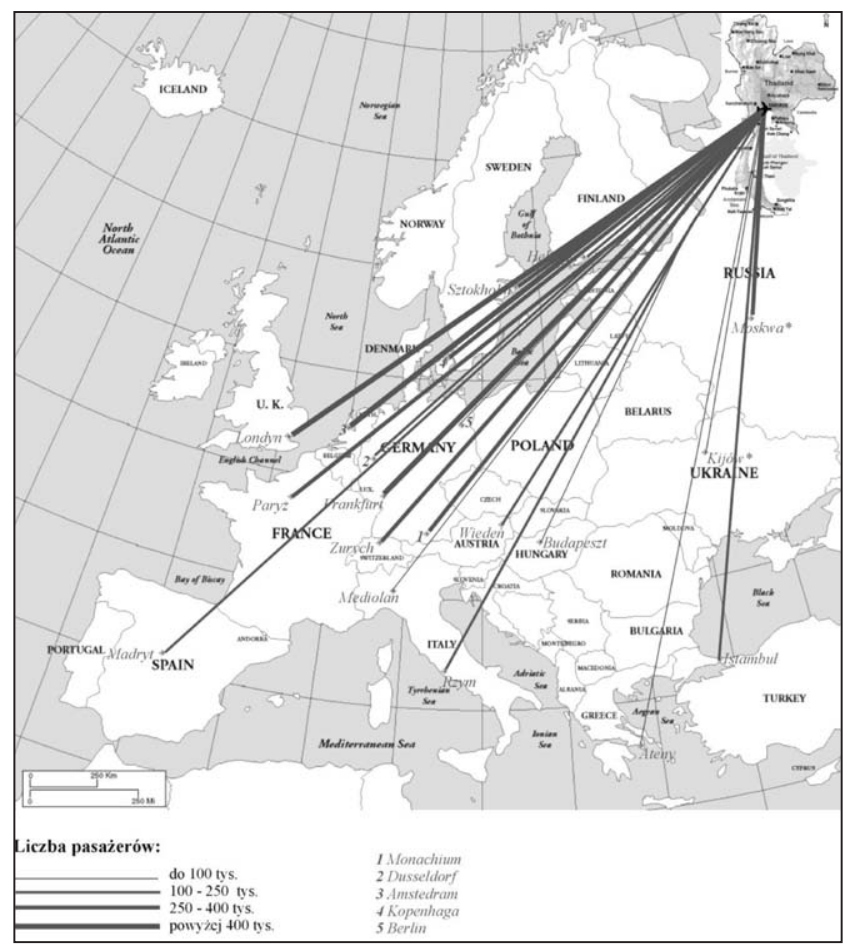

Źródło: opracowanie własne na podstawie www.suvarnabhumiairport.com

Bangkok Suvarnabhumi pełni rolę jednego z wielkich hubów Azji Połduniowo-Wschodniej. Jest też destynacją samą w sobie ze względu na wysoką rangę turystyki w Tajlandii. W $2007 \mathrm{r}$. port obsłużył łącznie 31,6 mln pasażerów międzynarodowych lotów rozkładowych i nierozkładowych, z czego $5 \mathrm{mln}$ to podróżni tras europejskich. Udział lotów europejskich w ruchu pasażerskim wynosił 11,3\% (obliczony na podstawie liczby bezpośrednich lotów do i z portu lotniczego). Stolica Tajlandii połączona była regularną komunikacją lotniczą z 20 miastami 
Europy (ryc. 2). Najbardziej obciążone połączenia poza Londynem to trasy do Frankfurtu (708 tys. pasażerów rocznie), Amsterdamu (410 tys.), Paryża (394 tys.) i Kopenhagi (393 tys.). W porcie obecnych było łącznie 20 europejskich linii lotniczych.

Ryc. 3. Europejskie połączenia lotnicze portu lotniczego w Kuala Lumpur

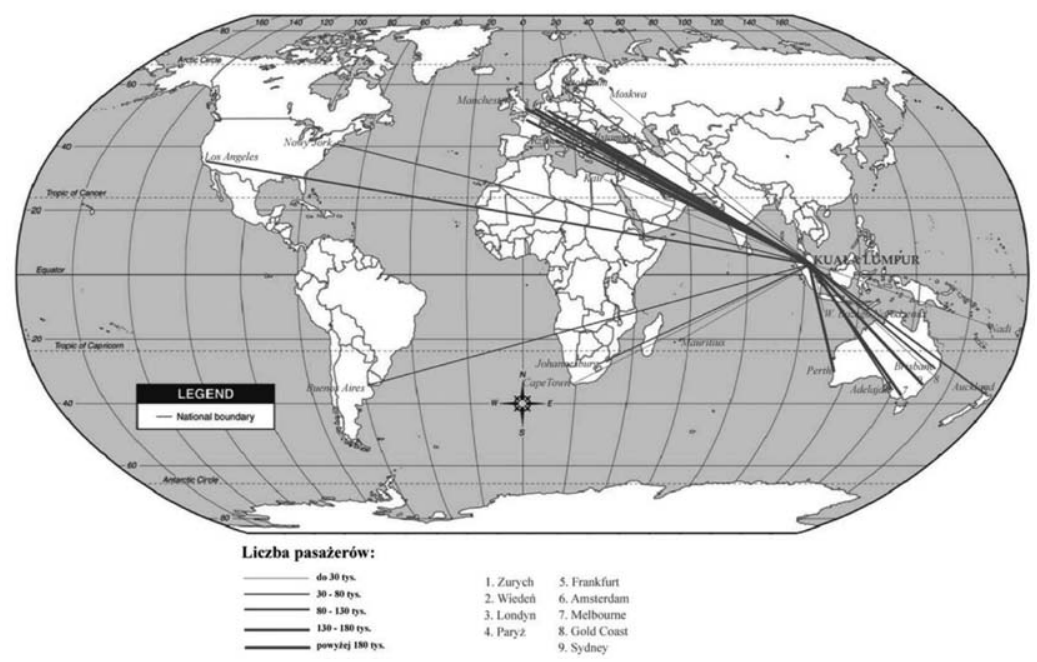

Źródło: opracowanie własne na podstawie www.klia.com.my

Port lotniczy Kuala Lumpur konkuruje z Singapurem w podróżach tranzytowych pomiędzy Europą a Australią. Jest jednak niekwestionowanym liderem jeśli chodzi o siatkę połączeń sektora low cost w regionie Azji Południowo-Wschodniej. Malezyjska tania linia lotnicza Air Asia jako pierwsza uruchomiła dalekodystansowe połączenia, które do tej pory były domeną wyłącznie tradycyjnych przewoźników. Do najdalszych destynacji operatora należy Wielka Brytania, Zjednoczone Emiraty Arabskie oraz Australia. Port lotniczy w Kuala Lumpur przyjął w 2007 r. 16,9 mln podróżnych międzynarodowych, z czego udział Europy w wielkości ruchu pasażerskiego stolicy Malezji wynosi 4,7\%. Stolica Malezji połączona była komunikacją lotniczą z 11 europejskimi metropoliami (ryc. 3). Oprócz Londynu najczęściej wybieranym miastem był Amsterdam (380 tys.), Paryż (159 tys.) oraz Frankfurt (141 tys.). Łącznie w omawianym porcie obecnych było jedynie trzech przewoźników pochodzących z Europy (Lufthansa, KLM i Transaero Airlines).

Singapur mimo swojej niewielkiej powierzchni od wieków pełni rolę miasta tranzytowego (w przeszłości - morskiego, a obecnie - przede wszystkim lotniczego), przez co posiada jeden z największych portów lotniczych w Azji. Liczba przyjazdów międzynarodowych w 2008 r. w porcie Singapur Changi wynosiła 7,2 mln., a udział Europy w wielkości ruchu pasażerskiego 7,3\%. Siatka połączeń europejskich opiera się na 14 trasach (ryc. 1) obsługiwanych przede wszystkim przez flagowego przewoźnika kraju Singapore Airlines. Na tutejszym rynku obecnych było siedmiu przewoźników z Europy (Air France, British Airways, KLM, Lufthansa, Swissair, Transaero Airlines, Turkish Airlines).

Żaden z omawianych portów lotniczych nie utrzymuje regularnej komunikacji z polskimi lotniskami. Funkcjonuja jedynie loty czarterowe (wykonywane przez Air Italy na trasie Warszawa-Bangkok) oraz połączenia na zasadzie porozumień codeshare. 


\section{Literatura}

1. Air Transports Statistics Suvarnabhumi Airport, 2007, Airports of Thailand Public Company Limited.

2. Bowen J., 2000, Airline hubs in Southeast Asia: national economic development and nodal accessibility, „Journal of Transport Geography” No 8, Elsevier, Amsterdam, s. 25-41.

3. Malaysia Airports Statistics, 2007, Malaysia Airports Holdings Bhd.

4. Milewski D., 2008, Przewozy turystyczne [w:] Gospodarka turystyczna, red. A. Panasiuk, PWN, Warszawa.

5. Pawlusiński R., 2007, Transport w turystyce [w:] Turystyka, red. W. Kurek, PWN, Warszawa.

6. Rydzykowski W., Wojewódzka-Król K. (red.), Transport, Wydawnictwo Naukowe PWN, Warszawa.

7. Wójtowicz M., 2005, Rozwój międzynarodowych powiazań lotniczych głównych polskich metropolii, „Biuletyn KPZK PAN”, z. 222, Warszawa.

\section{European Flight Connections with the Main Tourist Regions of Southeast Asia}

Transport plays a key role in satisfying the needs associated with tourist activity, both in regard to actually reaching one's destination as well as in regard to local transport in the area visited. East Asia and the Pacific is the most dynamically developing market of inbound tourism in the world. Between 2000-2008, international tourist arrivals increased by 67.2\% (74 mln). The sub-region of Southeast Asia was visited by $70.9 \%(36.1 \mathrm{mln})$ more tourists than 8 years before. Malaysia is the most frequently visited country in the region, with $22.1 \mathrm{mln}$ international arrivals in 2008, compared to $14.6 \mathrm{mln}$ in Thailand and $7.8 \mathrm{mln}$ in Singapore. Thailand has the largest influx of tourists followed by Malaysia. It is predicted that the importance of tourism in the region will continue to grow in the future. The percentage of international tourist arrivals to East Asia and the Pacific will have increased to $25 \%$ by 2020 . The key factor in the region is its accessibility as regards transport links, a factor which explains the rapid development of its airports, including the largest ones of Bangkok, Kuala Lumpur and Singapore. The present flight schedule (winter season 2009) has 338 connections between those cities and Europe, mostly from Bangkok (177). Singapore has 113 connections weekly with Europe while Kuala Lumpur only 48. None of these airports has regular connections with Polish airports except charter flights operated by Air Italy from Warsaw to Bangkok and connections under code share agreements. 